\title{
Microbulbifer celer sp. nov., isolated from a marine solar saltern of the Yellow Sea in Korea
}

\author{
Jung-Hoon Yoon, Seo-Youn Jung, So-Jung Kang and Tae-Kwang Oh \\ Korea Research Institute of Bioscience and Biotechnology (KRIBB), PO Box 115, Yusong, Taejon, \\ Korea
}

Correspondence

Jung-Hoon Yoon

jhyoon@kribb.re.kr

\begin{abstract}
A Gram-negative, non-motile, rod-shaped, Microbulbifer-like bacterial strain, ISL-39 ${ }^{\top}$, was isolated from a marine solar saltern of the Yellow Sea in Korea and was subjected to a polyphasic taxonomic investigation. Strain ISL-39 ${ }^{\top}$ grew optimally at $\mathrm{pH} 7.0-8.0$ and $37{ }^{\circ} \mathrm{C}$. It contained Q-8 as the predominant ubiquinone and iso- $C_{15: 0}, C_{16: 0}$ and iso- $C_{17: 0}$ as the major fatty acids. The DNA G + C content was 57.7 mol\%. A phylogenetic analysis based on 16S rRNA gene sequences showed that strain ISL-39 ${ }^{\top}$ belonged to the genus Microbulbifer. Strain ISL-39 exhibited 16S rRNA gene sequence similarity values of 94.7-97.5\% with respect to the type strains of four recognized Microbulbifer species. DNA-DNA relatedness data and the differential phenotypic properties and phylogenetic distinctiveness of ISL-39 ${ }^{\top}$ make this strain distinguishable from the recognized Microbulbifer species. On the basis of the phenotypic, phylogenetic and genetic data, strain ISL-39 ${ }^{\top}$ represents a novel species of the genus Microbulbifer, for which the name Microbulbifer celer sp. nov. is proposed. The type strain is ISL-39 ${ }^{\top}$ (=KCTC $12973^{\top}=$ CCUG $54356^{\top}$ ).
\end{abstract}

The genus Microbulbifer was erected by González et al. (1997) with the description of a single species, Microbulbifer hydrolyticus. Subsequently, two further Microbulbifer species, Microbulbifer salipaludis (Yoon et al., 2003a) and Microbulbifer maritimus (Yoon et al., 2004), were described. Pseudomonas elongata was reclassified into the genus Microbulbifer, as Microbulbifer elongatus (Yoon et al., 2003b). In this study, we report on the taxonomic characterization of a Microbulbifer-like bacterial strain $\left(\right.$ ISL-39 ${ }^{\mathrm{T}}$ ) that was isolated from a marine solar saltern of the Yellow Sea in Korea.

Strain ISL-39 $9^{\mathrm{T}}$ was isolated by means of the standard dilution plating technique, at $25{ }^{\circ} \mathrm{C}$ on marine agar 2216 (MA; Difco) supplemented with $6 \%(\mathrm{w} / \mathrm{v}) \mathrm{NaCl}$. The type strains of four Microbulbifer species were used as reference strains for DNA-DNA hybridization: M. hydrolyticus DSM $11525^{\mathrm{T}}$ and $M$. elongatus DSM $6810^{\mathrm{T}}$ were obtained from the Deutsche Sammlung von Mikroorganismen und Zellkulturen (Braunschweig, Germany) and M. salipaludis SM- $1^{\mathrm{T}}$ and $M$. maritimus $\mathrm{TF}-17^{\mathrm{T}}$ were obtained from previous studies (Yoon et al., 2003a, 2004). The morphological, physiological and biochemical characteristics of strain ISL- $39^{\mathrm{T}}$ were investigated using routine cultivation on MA at $37{ }^{\circ} \mathrm{C}$. The cell morphology was examined by using light microscopy (E600; Nikon) and transmission electron microscopy. Flagellation was investigated by using a CM-20 transmission electron microscope (Philips) with

The GenBank/EMBL/DDBJ accession number for the 16S rRNA gene sequence of strain ISL-39 ${ }^{\top}$ is EF486352. cells from exponentially growing cultures: for this purpose, the cells were negatively stained with $1 \%(\mathrm{w} / \mathrm{v})$ phosphotungstic acid and the grids were examined after being air-dried. Growth under anaerobic conditions was determined after incubation in a Forma anaerobic chamber on MA and on MA supplemented with nitrate, both of which had been prepared anaerobically using nitrogen. Growth in the absence of $\mathrm{NaCl}$ was investigated using trypticase soy broth prepared according to the formula of the Difco medium except that $\mathrm{NaCl}$ was excluded. Growth at various $\mathrm{NaCl}$ concentrations was investigated in marine broth 2216 (Difco) or trypticase soy broth (Difco). Growth at various temperatures $\left(4-50{ }^{\circ} \mathrm{C}\right)$ was measured on MA. Catalase and oxidase activities and hydrolysis of casein, starch and Tweens 20, 40, 60 and 80 were determined as described by Cowan \& Steel (1965). Hydrolysis of hypoxanthine, tyrosine and xanthine was tested on MA using the substrate concentrations described by Cowan \& Steel (1965). Hydrolysis of aesculin, gelatin and urea and nitrate reduction were investigated as described previously (Lanyi, 1987), except that artificial seawater was used for the preparation of media. The artificial seawater contained the following $\left(1^{-1}\right.$ distilled water): $23.6 \mathrm{~g} \mathrm{NaCl}, 0.64 \mathrm{~g} \mathrm{KCl}$, $4.53 \mathrm{~g} \mathrm{MgCl}_{2} \cdot 6 \mathrm{H}_{2} \mathrm{O}, 5.94 \mathrm{~g} \mathrm{MgSO}_{4} \cdot 7 \mathrm{H}_{2} \mathrm{O}$ and $1.3 \mathrm{~g}$ $\mathrm{CaCl}_{2} \cdot 2 \mathrm{H}_{2} \mathrm{O}$ (Bruns et al., 2001). $\mathrm{H}_{2} \mathrm{~S}$ production was tested as described previously (Bruns et al., 2001). Susceptibility to various antibiotics was investigated on MA plates by using antibiotic discs with the following concentrations: $100 \mathrm{U}$ polymyxin $\mathrm{B}, 50 \mu \mathrm{g}$ streptomycin, $20 \mathrm{U}$ penicillin G, $100 \mu \mathrm{g}$ chloramphenicol, $10 \mu \mathrm{g}$ ampicillin, $30 \mu \mathrm{g}$ cephalothin, $30 \mu \mathrm{g}$ gentamicin, $5 \mu \mathrm{g}$ novobiocin, 
$30 \mu \mathrm{g}$ tetracycline, $30 \mu \mathrm{g}$ kanamycin, $15 \mu \mathrm{g}$ lincomycin, $15 \mu \mathrm{g}$ oleandomycin, $30 \mu \mathrm{g}$ neomycin and $100 \mu \mathrm{g}$ carbenicillin. Acid production from carbohydrates was tested as described by Leifson (1963). The utilization of various substrates for growth was determined as described by Yurkov et al. (1994). Enzyme activities were determined by using the API ZYM system (bioMérieux).

Cell biomass for DNA extraction and for isoprenoid quinone analysis was obtained from cultivation in marine broth 2216 at $37{ }^{\circ} \mathrm{C}$. Chromosomal DNA was isolated and purified according to the method described by Yoon et al. (1996), except that RNase T1 was used in combination with RNase A to minimize contamination from RNA. The 16S rRNA gene was amplified by using PCR with two universal primers, as described previously (Yoon et al., 1998). Sequencing of the amplified 16S rRNA gene and the phylogenetic analysis were performed as described by Yoon et al. (2003a). Isoprenoid quinones were investigated as described by Komagata \& Suzuki (1987), using reversedphase HPLC. For cellular fatty acid analysis, cell mass was harvested from MA plates after cultivation of strain ISL$39^{\mathrm{T}}$ for 2 days at $37^{\circ} \mathrm{C}$. The fatty acids were extracted and the fatty acid methyl esters prepared according to the standard protocol of the MIDI/Hewlett Packard Microbial Identification System (Sasser, 1990). The DNA G+C content was determined by using the method of Tamaoka \& Komagata (1984), with the modification that the DNA was hydrolysed using nuclease P1 (Sigma) and the resultant nucleotides were analysed by reversed-phase HPLC. DNADNA hybridization was performed fluorometrically according to the method of Ezaki et al. (1989), using photobiotin-labelled DNA probes and microdilution wells. Hybridization was performed with five replications for each sample. The highest and lowest values obtained in each sample were excluded and the means of the remaining three values were quoted as the DNA-DNA relatedness values.

Morphological, cultural, physiological and biochemical characteristics of strain ISL- $39^{\mathrm{T}}$ are given in the species description (see below) or in Table 1. The almost-complete $16 \mathrm{~S}$ rRNA gene sequence of strain ISL- $39^{\mathrm{T}}$ determined in this study comprised $1491 \mathrm{nt}$, representing approximately $96 \%$ of the Escherichia coli 16S rRNA gene sequence. Comparative 16S rRNA gene sequence analysis revealed that strain ISL-39 ${ }^{\mathrm{T}}$ was most closely related phylogenetically to members of the genus Microbulbifer. In the phylogenetic tree based on the neighbour-joining algorithm, strain ISL- $39^{\mathrm{T}}$ fell within the clade comprising the Microbulbifer species (Fig. 1). Strain ISL-39 ${ }^{\mathrm{T}}$ exhibited $16 \mathrm{~S}$ rRNA gene sequence similarity values of $97.5,97.5,96.2$, 94.7 and $94.5 \%$ with respect to the type strains of $M$. hydrolyticus, M. salipaludis, M. elongatus, M. maritimus and 'Microbulbifer arenaceous', respectively. The values for sequence similarity with respect to other species used in the phylogenetic analysis were below $90.8 \%$. The chemotaxonomic properties of ISL- $39^{\mathrm{T}}$ confirm the phylogenetic results, indicating an affiliation with the genus
Microbulbifer (González et al., 1997; Yoon et al., 2003a, b, 2004). The predominant isoprenoid quinone detected in strain ISL-39 ${ }^{\mathrm{T}}$ was Q-8 (at a peak area ratio of approximately $92 \%$ ). The fatty acid profile of strain ISL$39^{\mathrm{T}}$ showed the presence of large amounts of branched, straight-chain, unsaturated, hydroxyl and cyclo fatty acids; the major components ( $>10 \%$ of total fatty acids) were iso- $\mathrm{C}_{15: 0}, \mathrm{C}_{16: 0}$ and iso- $\mathrm{C}_{17: 0}$ (Table 2). This fatty acid profile was similar to those of the Microbulbifer species, although there were differences in the proportions of some fatty acids, probably because of differences in cultivation conditions and extraction procedures (Table 2). The DNA $\mathrm{G}+\mathrm{C}$ content of strain ISL-39 ${ }^{\mathrm{T}}$ was $57.7 \mathrm{~mol} \%$. Strain ISL$39^{\mathrm{T}}$ exhibited DNA-DNA relatedness values of $7-16 \%$ with respect to the type strains of four recognized Microbulbifer species, indicating that ISL- $39^{\mathrm{T}}$ represents a different genomic species (Wayne et al., 1987). Strain ISL$39^{\mathrm{T}}$ is distinguishable from the recognized Microbulbifer species through differences in several phenotypic characteristics, as shown in Table 1 . The phylogenetic and genetic distinctiveness of ISL-39 ${ }^{\mathrm{T}}$, together with the differential phenotypic properties, are sufficient to permit the allocation of this strain to a species that is separate from the recognized Microbulbifer species (Wayne et al., 1987; Stackebrandt \& Goebel, 1994). Therefore, on the basis of the data presented, strain ISL- $39^{\mathrm{T}}$ represents a novel species of the genus Microbulbifer, for which the name Microbulbifer celer sp. nov. is proposed.

\section{Description of Microbulbifer celer sp. nov.}

Microbulbifer celer (ce'ler. L. masc. adj. celer rapid, pertaining to fast growth).

Cells are Gram-negative and rod-shaped $(0.2-0.4 \times 0.8-$ $3.5 \mu \mathrm{m})$. Colonies on MA are circular to slightly irregular, slightly convex, smooth, glistening, greyish yellow in colour and $3.0-4.0 \mathrm{~mm}$ in diameter after 2 days incubation at $37^{\circ} \mathrm{C}$. Growth occurs at 10 and $48{ }^{\circ} \mathrm{C}$, but not at 4 or $49^{\circ} \mathrm{C}$. The optimal pH for growth is between 7.0 and 8.0; growth occurs at $\mathrm{pH}$ 5.0, but not at $\mathrm{pH} 4.5$. Growth occurs in the presence of $15 \%(\mathrm{w} / \mathrm{v}) \mathrm{NaCl}$, but not in the absence of $\mathrm{NaCl}$ or in the presence of more than $16 \%(\mathrm{w} / \mathrm{v}) \mathrm{NaCl}$. Anaerobic growth does not occur on MA or on MA supplemented with nitrate. Hypoxanthine and Tweens 20, 40 and 60 are hydrolysed, but urea, L-tyrosine and xanthine are not. Acetate and pyruvate are utilized, but D-glucose, Dfructose, D-galactose, D-cellobiose, D-mannose, trehalose, D-xylose, L-arabinose, sucrose, maltose, citrate, succinate, benzoate, L-malate, salicin, formate and L-glutamate are not utilized. Acid is produced from melibiose, but not from D-mannitol, D-melezitose, D-raffinose, L-rhamnose, D-ribose, D-sorbitol or myo-inositol. Susceptible to chloramphenicol, kanamycin, neomycin and novobiocin and weakly susceptible to oleandomycin and polymyxin $\mathrm{B}$, but not to ampicillin, carbenicillin, cephalothin, gentamicin, lincomycin, penicillin $\mathrm{G}$, streptomycin or tetracycline. The predominant ubiquinone is Q-8. The major fatty acids $\left(>10 \%\right.$ of total fatty acids) are iso- $\mathrm{C}_{15: 0}, \mathrm{C}_{16: 0}$ and 
Table 1. Differential phenotypic characteristics of strain ISL-39 ${ }^{\top}$ and Microbulbifer species

Strain Species: 1, ISL-39 ${ }^{\mathrm{T}}$, data from this study; 2, M. hydrolyticus, data from González et al. (1997), Yoon et al. (2003a) and this study; 3, M. salipaludis, data from Yoon et al. (2003a) and this study; 4, M. elongatus, data from Humm (1946) and this study; 5, M. maritimus, data from Yoon et al. (2004). All of the species are positive for the following: catalase and oxidase activities (data for M. hydrolyticus and M. elongatus from this study), alkaline phosphatase, esterase (C4), lipase (C8), leucine arylamidase, acid phosphatase, naphthol-AS-BI-phosphohydrolase; hydrolysis of starch and Tween 80 (data for M. hydrolyticus and M. elongatus from this study); growth at pH 6.0 and $10 \% \mathrm{NaCl}$ (data for M. hydrolyticus and M. elongatus from this study); acid production from D-cellobiose. All species are negative for spore formation, Gram-staining, lipase (C14), valine arylamidase, cystine arylamidase, trypsin, $\alpha$-chymotrypsin, $\alpha$-galactosidase, $\beta$-galactosidase, $\beta$-glucuronidase, $\alpha$-glucosidase, $\beta$-glucosidase, $\alpha$ mannosidase, $\alpha$-fucosidase, acid production from D-fructose and D-mannose and growth at $0 \% \mathrm{NaCl}$. + , Positive reaction; -, negative reaction; $\mathrm{W}$, weakly positive reaction.

\begin{tabular}{|c|c|c|c|c|c|}
\hline Characteristic & 1 & 2 & 3 & 4 & 5 \\
\hline Colony colour & Greyish yellow & Cream & Greyish yellow & Yellowish brown & Yellowish brown \\
\hline Reduction of nitrate to nitrite & - & $-{ }^{\star}$ & $+\dagger$ & $-{ }^{\star}$ & - \\
\hline \multicolumn{6}{|l|}{ Hydrolysis of: } \\
\hline Aesculin & + & $+^{*}$ & - & $+^{*}$ & - \\
\hline Casein & + & $+^{*}$ & $\mathrm{w}$ & $+^{*}$ & + \\
\hline Gelatin & - & $+^{*}$ & $-\dagger$ & $+^{*}$ & + \\
\hline \multicolumn{6}{|l|}{ Acid production from: $\dagger$} \\
\hline L-Arabinose & + & + & - & + & - \\
\hline D-Galactose & + & - & - & + & - \\
\hline D-Glucose & - & + & + & + & - \\
\hline D-Xylose & + & + & - & + & - \\
\hline$N$-Acetyl- $\beta$-glucosaminidase (API ZYM) $\ddagger$ & + & - & + & + & - \\
\hline Optimum growth temperature $\left({ }^{\circ} \mathrm{C}\right)$ & 37 & 37 & 37 & $25-30$ & 37 \\
\hline DNA G $+\mathrm{C}$ content $(\mathrm{mol} \%)$ & 57.7 & $58.2^{\star}$ & 59 & $58.2^{\star}$ & 59.9 \\
\hline
\end{tabular}

${ }^{\star}$ Data for M. hydrolyticus and M. elongatus from this study.

$\dagger$ Data for M. elongatus from this study.

$\ddagger$ Data for M. salipaludis from this study.

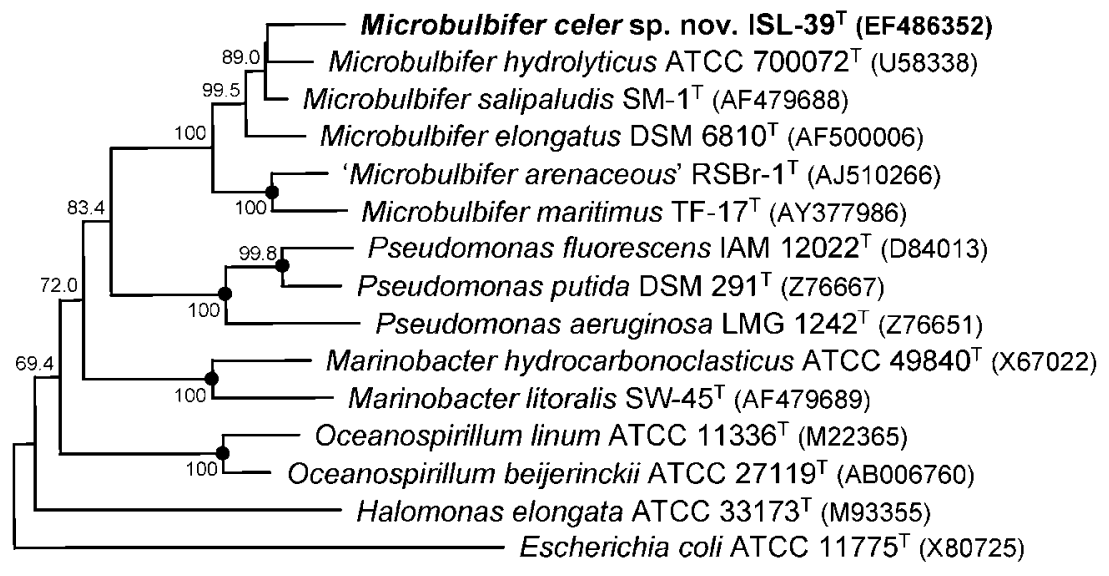

$\underline{0.01}$
Fig. 1. Neighbour-joining phylogenetic tree, based on 16S rRNA gene sequences, showing the positions of strain ISL-39 ${ }^{\top}$, Microbulbifer species and some other related taxa. Bootstrap percentages (based on 1000 replications) $>50 \%$ are shown at branch points. Filled circles indicate that the corresponding nodes were also recovered in the trees generated with the maximum-likelihood and maximum-parsimony algorithms. E. coli ATCC $11775^{\top}$ was used as an outgroup. Bar, 0.01 substitutions per nucleotide position. 
Table 2. Cellular fatty acid composition (\%) for strain ISL-39 ${ }^{\top}$ and other Microbulbifer species

Strains: 1, ISL-39 ${ }^{\mathrm{T}} ; 2$, M. hydrolyticus DSM $11525^{\mathrm{T}} ; 3$, M. salipaludis SM- $1^{\mathrm{T}} ; 4$, M. elongatus DSM $6810^{\mathrm{T}} ; 5$, M. maritimus TF- $17^{\mathrm{T}}$. Data for 2-5 are from Yoon et al. (2004). Fatty acids representing less than $0.5 \%$ in all strains have been omitted. The results presented were obtained using identical methods. -, Not detected.

\begin{tabular}{|c|c|c|c|c|c|}
\hline Fatty acid & 1 & 2 & 3 & 4 & 5 \\
\hline \multicolumn{6}{|l|}{$\begin{array}{l}\text { Straight-chain fatty } \\
\text { acids }\end{array}$} \\
\hline $\mathrm{C}_{10: 0}$ & 1.6 & 1.7 & 2.4 & 1.6 & 1.3 \\
\hline $\mathrm{C}_{14: 0}$ & 0.9 & 1.2 & 2.6 & 0.7 & 1.0 \\
\hline $\mathrm{C}_{15: 0}$ & 1.5 & 1.5 & 1.7 & 0.9 & 1.6 \\
\hline $\mathrm{C}_{16: 0}$ & 12.6 & 11.4 & 16.3 & 7.1 & 8.7 \\
\hline $\mathrm{C}_{17: 0}$ & 2.6 & 2.9 & 2.2 & 2.5 & 1.3 \\
\hline $\mathrm{C}_{18: 0}$ & 0.8 & 1.6 & 1.4 & 1.2 & - \\
\hline \multicolumn{6}{|l|}{$\begin{array}{l}\text { Branched fatty } \\
\text { acids }\end{array}$} \\
\hline iso- $\mathrm{C}_{11: 0}$ & 6.7 & 5.7 & 4.8 & 6.5 & 10.0 \\
\hline iso- $\mathrm{C}_{15: 0}$ & 21.7 & 24.4 & 19.4 & 20.7 & 25.9 \\
\hline iso- $\mathrm{C}_{15: 1} \mathrm{~F}^{*}$ & 0.4 & 1.0 & 0.7 & 1.0 & 0.8 \\
\hline iso- $\mathrm{C}_{16: 0}$ & 0.3 & - & - & 0.5 & - \\
\hline iso- $\mathrm{C}_{17: 0}$ & 10.0 & 10.4 & 5.5 & 9.9 & 6.9 \\
\hline anteiso- $\mathrm{C}_{17: 0}$ & 0.3 & - & - & 0.8 & - \\
\hline iso- $\mathrm{C}_{17: 1} \omega 9 c$ & 8.6 & 10.1 & 9.5 & 11.3 & 12.6 \\
\hline \multicolumn{6}{|l|}{$\begin{array}{l}\text { Unsaturated fatty } \\
\text { acids }\end{array}$} \\
\hline $\mathrm{C}_{17: 1} \omega 8 c$ & 0.5 & 0.5 & 1.0 & 1.8 & - \\
\hline $\mathrm{C}_{18: 1} \omega 5 c$ & - & - & 0.7 & - & - \\
\hline $\mathrm{C}_{18: 1} \omega 7 c$ & 6.5 & 8.9 & 11.8 & 16.3 & 5.6 \\
\hline \multicolumn{6}{|l|}{ Hydroxy fatty acids } \\
\hline $\mathrm{C}_{10: 0} 3-\mathrm{OH}$ & 1.4 & 1.0 & 1.2 & 1.6 & 1.7 \\
\hline $\mathrm{C}_{16: 0} 2-\mathrm{OH}$ & - & - & 0.9 & - & - \\
\hline iso- $\mathrm{C}_{11: 0} 3-\mathrm{OH}$ & 8.9 & 6.2 & 5.7 & 7.7 & 14.2 \\
\hline iso- $\mathrm{C}_{17: 0} 3-\mathrm{OH}$ & - & - & 0.9 & - & - \\
\hline \multicolumn{6}{|l|}{ Cyclo fatty acids } \\
\hline $\mathrm{C}_{17: 0}$ cyclo & 6.3 & 5.7 & - & - & 2.3 \\
\hline $\mathrm{C}_{19: 0}$ cyclo $\omega 8 \mathrm{c}$ & 5.3 & 1.0 & - & - & 1.4 \\
\hline \multicolumn{6}{|l|}{ Summed features $\dagger$} \\
\hline 3 & 2.4 & 2.7 & 7.1 & 6.0 & 2.2 \\
\hline 4 & - & - & 1.7 & - & - \\
\hline
\end{tabular}

*The double-bond position, indicated by a capital letter, is unknown. $\dagger$ Summed features represent groups of two or three fatty acids that could not be separated by GLC with the MIDI system. Summed feature 3 contained one or more of the following fatty acids: iso- $\mathrm{C}_{15: 0}$ 2-OH and/or $\mathrm{C}_{16: 1} \omega 7 c$. Summed feature 4 contained one or more of the following fatty acids: anteiso- $\mathrm{C}_{17: 1} \mathrm{~B}$ and/or iso- $\mathrm{C}_{17: 1} \mathrm{I}$.

iso- $\mathrm{C}_{17: 0}$. The DNA $\mathrm{G}+\mathrm{C}$ content is $57.7 \mathrm{~mol} \%$ (determined by HPLC). Other phenotypic characteristics are given in Table 1.

The type strain, ISL $-39^{\mathrm{T}} \quad\left(=\mathrm{KCTC} \quad 12973^{\mathrm{T}}=\mathrm{CCUG}\right.$ $\left.54356^{\mathrm{T}}\right)$, was isolated from a marine solar saltern of the Yellow Sea in Korea.

\section{Acknowledgements}

This work was supported by the 21C Frontier Program of Microbial Genomics and Applications (grant MG05-0401-2-0) and the Support and Application Project of Biological Resources (grant M10508050004-06N0805-00410) from the Ministry of Science and Technology (MOST) of the Republic of Korea, and by a grant from the KRIBB Research Initiative Program.

\section{References}

Bruns, A., Rohde, M. \& Berthe-Corti, L. (2001). Muricauda ruestringensis gen. nov., sp. nov., a facultatively anaerobic, appendaged bacterium from German North Sea intertidal sediment. Int $J$ Syst Evol Microbiol 51, 1997-2006.

Cowan, S. T. \& Steel, K. J. (1965). Manual for the Identification of Medical Bacteria. London: Cambridge University Press.

Ezaki, T., Hashimoto, Y. \& Yabuuchi, E. (1989). Fluorometric deoxyribonucleic acid-deoxyribonucleic acid hybridization in microdilution wells as an alternative to membrane filter hybridization in which radioisotopes are used to determine genetic relatedness among bacterial strains. Int J Syst Bacteriol 39, 224-229.

González, J. M., Mayer, F., Moran, M. A., Hodson, R. E. \& Whitman, W. B. (1997). Microbulbifer hydrolyticus gen. nov., sp. nov., and Marinobacterium georgiense gen. nov., sp. nov., two marine bacteria from a lignin-rich pulp mill waste enrichment community. Int J Syst Bacteriol 47, 369-376.

Humm, H. J. (1946). Marine agar-digesting bacteria of the South Atlantic coast. Bull Duke Univ Mar Stn 3, 45-75.

Komagata, K. \& Suzuki, K. (1987). Lipid and cell wall analysis in bacterial systematics. Methods Microbiol 19, 161-207.

Lanyi, B. (1987). Classical and rapid identification methods for medically important bacteria. Methods Microbiol 19, 1-67.

Leifson, E. (1963). Determination of carbohydrate metabolism of marine bacteria. J Bacteriol 85, 1183-1184.

Sasser, M. (1990). Identification of Bacteria by Gas Chromatography of Cellular Fatty Acids, MIDI Technical Note 101. Newark, DE: MIDI Inc.

Stackebrandt, E. \& Goebel, B. M. (1994). Taxonomic note: a place for DNA-DNA reassociation and $16 \mathrm{~S}$ rRNA sequence analysis in the present species definition in bacteriology. Int J Syst Bacteriol 44, 846-849.

Tamaoka, J. \& Komagata, K. (1984). Determination of DNA base composition by reversed-phase high-performance liquid chromatography. FEMS Microbiol Lett 25, 125-128.

Wayne, L. G., Brenner, D. J., Colwell, R. R., Grimont, P. A. D., Kandler, O., Krichevsky, M. I., Moore, L. H., Moore, W. E. C., Murray, R. G. E. \& other authors (1987). International Committee on Systematic Bacteriology. Report of the ad hoc committee on reconciliation of approaches to bacterial systematics. Int J Syst Bacteriol 37, 463-464.

Yoon, J.-H., Kim, H., Kim, S.-B., Kim, H.-J., Kim, W. Y., Lee, S. T., Goodfellow, M. \& Park, Y.-H. (1996). Identification of Saccharomonospora strains by the use of genomic DNA fragments and rRNA gene probes. Int J Syst Bacteriol 46, 502-505.

Yoon, J.-H., Lee, S. T. \& Park, Y.-H. (1998). Inter- and intraspecific phylogenetic analysis of the genus Nocardioides and related taxa based on 16S rDNA sequences. Int J Syst Bacteriol 48, 187-194.

Yoon, J.-H., Kim, I.-G., Shin, D.-Y., Kang, K. H. \& Park, Y.-H. (2003a). Microbulbifer salipaludis sp. nov., a moderate halophile isolated from a Korean salt marsh. Int J Syst Evol Microbiol 53, 53-57.

Yoon, J.-H., Kim, H., Kang, K. H., Oh, T.-K. \& Park, Y.-H. (2003b). Transfer of Pseudomonas elongata Humm 1946 to the genus 
Microbulbifer as Microbulbifer elongatus comb. nov. Int J Syst Evol Microbiol 53, 1357-1361.

Yoon, J.-H., Kim, I.-G., Oh, T.-K. \& Park, Y.-H. (2004). Microbulbifer maritimus sp. nov., isolated from an intertidal sediment from the Yellow Sea, Korea. Int J Syst Evol Microbiol 54, 1111-1116.
Yurkov, V., Stackebrandt, E., Holmes, A., Fuerst, J. A., Hugenholtz, P., Golecki, J., Gad'on, N., Gorlenko, V. M., Kompantseva, E. I. \& Drews, G.

(1994). Phylogenetic positions of novel aerobic, bacteriochlorophyll $a$ containing bacteria and description of Roseococcus thiosulfatophilus gen. nov., sp. nov., Erythromicrobium ramosum gen. nov., sp. nov., and Erythrobacter litoralis sp. nov. Int J Syst Bacteriol 44, 427-434. 